\title{
阪神・淡路大震災後の地区内街路空間の管理における 行政之住民の役割に関する事例研究
}

\section{A Study on the Partnership between Goverment and Neighborhoods Residents on Maintenance of Street on Nishisuma District, Suma Ward, Kobe City, after the Great Hanshin-Awaji Earthquake}

浅野智子* 野嶋政和*

Satoko ASANO Masakazu NOJIMA

\begin{abstract}
摘要 : 本稿は, 地区内街路空間の整備・管理の実態と今日的課題を明らかにすることを目的に，神戸 市須磨区西須磨地区を事例地とし，街路空間の特質，震災後の行政と地域組織（自治会）の地区内街 路空間整備・管理について分析した。その結果(1)事例地の街路空間は，幅員，整備状況，施設配置に おいて課題を抱えていること，(2)街路の管理主体により，震災後の整備状況には格差があること，(3) 整備助成制度の運用面の観点から, 今後の街路整備における行政と住民のパートナーシップが必要と されること、(4)震災後の住民による組織的な空間管理が一定の成果を収めたことから，今後の空間整 備において重要な役割を果たす可能性をもつことが示唆された。
\end{abstract}

\section{1.はじめに}

阪神・淡路大震災は既成市街地の抱える住宅の密集, 老朽化, オープンスペースの不足，人口の流出，高齢化等の空間的課題を 顕在化した。造園学の対象領域であるオープンスペースに関して は, 学校等と共に公園, 街路, 河川敷等が物資配給, 情報収集の 地域センター，一時的避難の場，仮設住宅用地等に利用され，多 様な機能を持つことが再評価されている。また震災時のオープン スペース利用では，既存の地域住民組織を母体とし，個人やボラ ンティアを巻き込んだ，組織的利用が報告されている1)。

オープンスペースとコミュニティの関係に着目すると，コミュ ニティによる空間利用とともに，これに対応する行為である空間 管理の側面に注目する必要がある。特に既成市街地の地区内街路 空間は幹線道路之は異なり，行政が制度的手法により，空間管理 全てを担うには限界があり，地権者や地域住民組織が管理の一部 を担う状況がある。本稿の目的は，街路空間の制度的な管理の実 態から，街路空間管理における住民と行政の制度的位置つけと， 今日的課題を明らかにすること，街路空間管理の実態におけるコ ミュニティ一特に地域住民組織一の役割を検証することであ る。今後のオープンスペース整備において，住民と行政のパートナー シップを形成し深化させる上で有用な知見となり得ると考える。 オープンスペースとコミュニティの関係を扱った研究では，空

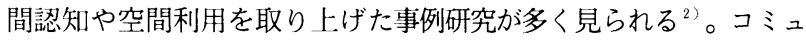
ニティによる空間管理や空間の整備・管理における行政と住民の 役割について，特に住民の役割に関しては，空間管理や計画策定 の合意形成プロセスにおける地域住民組織の役割が論じられてい る ${ }^{3)}$ 。しかし，既往研究では集合住宅地を取り上げたものは多い が，既成市街地は少なく，今後事例研究を蓄積する必要がある。

本稿では，既成市街地であり，阪神大震災の被災地である神戸 市須磨区西須磨地区を事例地とし，地区内街路空間の整備・管理 の実態と課題を検討していく4)。街路空間の管理に関わる地域住 民組織としては自治会を取り上げ，5つの自治会を選定した ${ }^{5)}$ 。

本稿の構成は以下の通りである。(1)被災地の既成市街地として の街路空間の特質を把握するため, 事例地の空間形態, 管理主体, 震災後の街路空間整備の方法と進渉状況について分析する。(2)地 域住民組織の街路空間の管理の実態を把握するため，事例地にお ける，震災前から現在までの街路空間に纏わる課題の発生と自治 会の対応の状況について分析する。(3)事例地の街路空間が抱える
課題と街路空間管理におけるコミュニティの役割を通して，事例 地における今後の街路空間整備の方向性について考察する。

\section{2. 調査方法}

\section{(1) 空間形態}

空間形態については 1998 年 7 月時点での実測調査を行った。 調査内容は街路幅員, 舖装状態, 建て替え状況, セットバック実 施状況である。街路施設整備については，1震災後の街路整備状 況, 私道整備助成申請状況は神戸市の災害復旧事業関係図面 ${ }^{5)}$, (2)街路管理については神戸市の公道位置図 ${ }^{7}$ および神戸市認定路 線一覧表, (3)その他の地区内街路空間に付属する施設は関係部局 の配置図等，整備一覧表，住民の聞き取り調査を行った。

\section{（2）地域住民，行政の空間管理の実態}

1998 年 $9 \sim 10$ 月時点での自治会の役員層, 行政関係部局職員 への聞き取り調查を行った。調査項目は, 震災前〜震災時〜復興 期 $^{8)}$ の行政および各自治会のオープンスペースの管理内容と, 各 自治会の会則, 運営の方法と実態などである。その他自治会報 ${ }^{9}$, 行政資料等の文献による調查を行った。

\section{3. 事例地}

西須磨地区は神戸市の既成市街地最西端に位置し, 明治以降, 保養地, 別荘地として開発され, 現在は神戸の産業の中心地と市 内西部のニュータウンとの結節点に位置している。地域内では, 事例地の南東部が戦災を受け, 戦災復興区画整理事業が完了して いる。しかし他の区域は細街路が密集し, 震災前は木造を中心と した低層住宅地であった。用途は幹線沿いが近隣商業地域や商業 地域，第一種住居専用地域に指定されているが，その他は第一種 低層住居専用地域と第一種中高層住居地域である。1994 年に事 例地を含む地域一帯に対し, 行政より区画整理事業が検討された が，事業化決定直前で住民の反対に遭い，事業化決定がなされな いまま震災を迎えた。震災によって事例地の南西部を中心に大き な被害を被った。

本稿で取り上げる 5 自治会は, 西須磨地区の一部をなし ${ }^{10)}$, 東 上り月見山連合自治会 (以下月見山), 東部自治会 (東部), 桜木 町自治会 (桜木) 天神町 $3 \cdot 4 \cdot 5$ 丁目自治会 (天神), 須磨本 町自治会（本町）である。 5 自治会の面積及び人口, 施設の整備 状況，活動の経緯には差が見られる。震災によって人口は激減し

*京都大学大学院農学研究科 


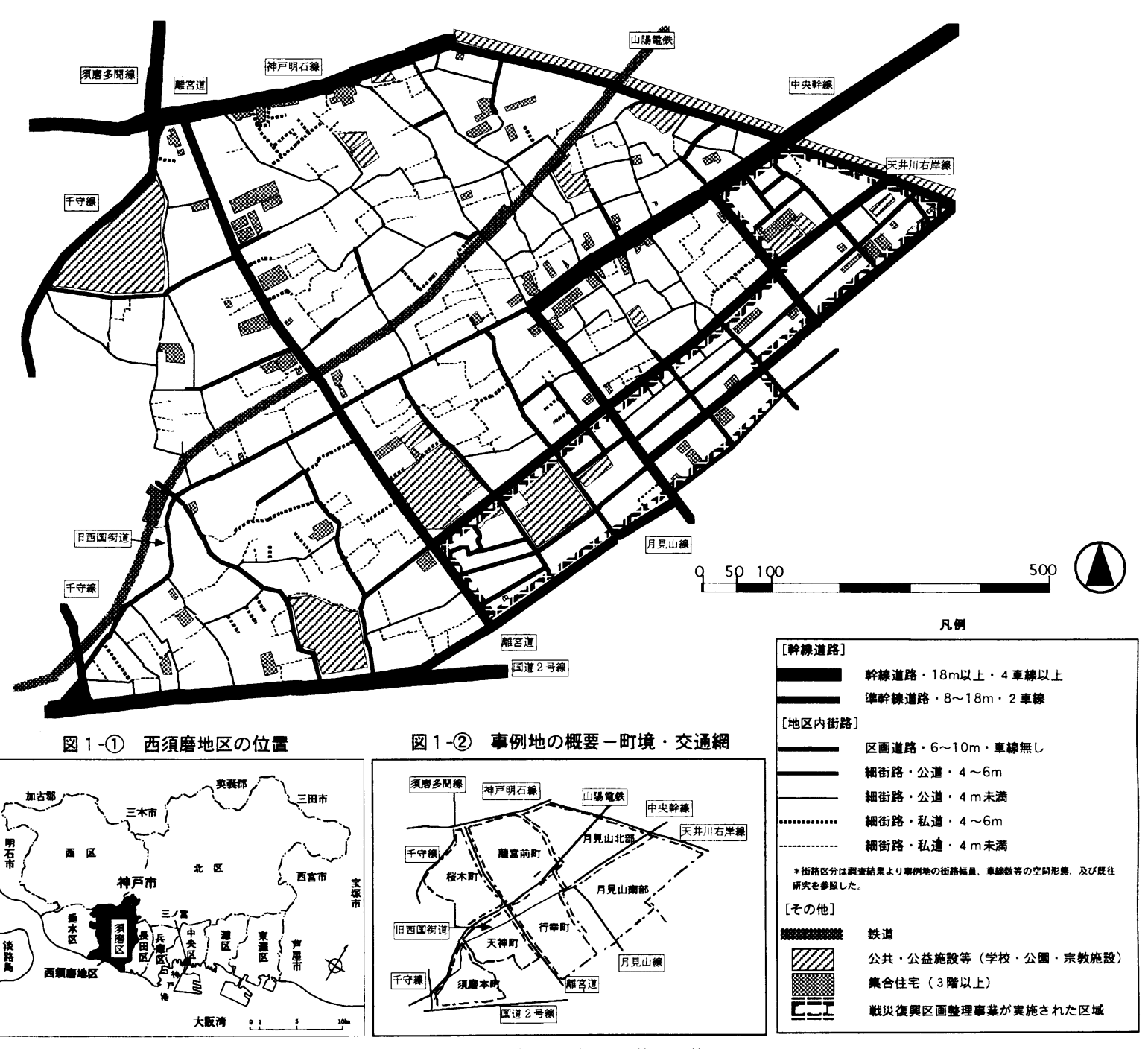

図-1 西須磨地区街路形態及び概要

たが，現在は回復しつつある（表一 1 及び表 -3 )。各自治会は 現在, 独自に活動を行っているが, 桜木, 天神, 本町の各自治会 は, 震災前は周辺自治会之共に西須磨西部連合自治会を構成して いた。震災後の 1996 年に西須磨西部連合自治会は改編され, 単 位自治会として独自性を強めて活動するようになった。

\section{4.事例地における街路空間の実態}

本節では事例地の街路空間の特質を把握するため, 以下の分析 を行った。(1)まず街路空間の概況として, 空間形態により区分さ れる街路区分（幅員），および管理主体による街路区分（公道， 私道）の配置を取り上げる。(2次に震災後, 街路形態と管理主体 に応じて進められてきた管理の実態として, 街路本体の整備状況 (舗装, 側溝) と, 街路が地域の生活空間として機能するために 不可欠な付属施設 (街灯, 掲示板, 消火器) の整備状況について 取り上げる。(3)街路の空間形態, 管理主体, 整備状況から, 事例 地における街路空間の管理の実態について分析を行う。図ー 1 に は街路幅員および管理主体の観点から, 事例地の街路を7つに分 類して示した。幅員による街路区分は，18m以上で 4 車線以上を 幹線道路, $8 \sim 18 \mathrm{~m}$ で 2 車線以上を準幹線道路, 6 10m で車線 無しを区画道路， $6 \mathrm{~m}$ 以下を細街路とし, 細街路を更に建築基準 法や事例地を管轄する須磨消防署の防災計画図（1997 年）に基 づき, 幅員 $4 \mathrm{~m}$ 以上, $4 \mathrm{~m}$ 末満に分類した。

\section{(1) 街路幅員}

事例地全体の幅員別の街路長をみると, 幹線道路が $1547 \mathrm{~m}$, 準幹線道路が $1622 \mathrm{~m}$ である。これらの幹線道路および準幹線道 路を除く地域内街路では, 総延長 $22036.4 \mathrm{~m}$ のうち, 幅員 $4 \mathrm{~m}$ 以 上の細街路が $41.2 \%, 4 \mathrm{~m}$ 末満の細街路が $58.8 \%$ である。幅員 $4 \mathrm{~m}$ 末満の細街路が袋小路, 通り抜けのどちらにおいても広く分 布しており, 震災後, 被災地で建て替えが進まない要因の一つ之 して挙げられる。幅員 $4 \mathrm{~m}$ 以上の細街路は旧西国街道などで, 事 例地に拀いては区画道路としての機能を担っている。しかし一方 通行や対面通行には狭险であったり, 歩車が分離しておらず, 非 常時の救援救出作業が困難であったり, 交通事故の危険性があり, 安全上問題がある。それ以外の幅員 $4 \mathrm{~m}$ 以上の細街路は, (1)離宮 道に面し, 震災前よりマンション開発で建物をセットバックした ものか, (2)区画の内部に位置し, 震災前のミ二開発や震災後の建 て替え時にセットバックしたものが多い。しかし倒壊率が高く, 震災後再建戸数の多い地区（本町, 天神) でも, $4 \mathrm{~m}$ 末満の細街 路が $55 \%$ 以上にぼり, 再建時の建築物及び垪の壁面後退が不 十分で, $4 \mathrm{~m}$ 幅員の街路が確保されていないことを示している。 次に幅員別の街路分布について, 各自治会の管理範囲区分との 関係から把握するため, 区画整理実施状況および幹線道路に着目 して地区区分を行うと, 事例地は 4 つに分割される。1 1 月見山南 部の一部および東部の南端では, 区画整理が実施されている。区 画は主に区画街路および $4 \mathrm{~m}$ 以上の細街路で東西と南北に区割り 
表 -1 各自治会の空間的概況および街路空間の実態

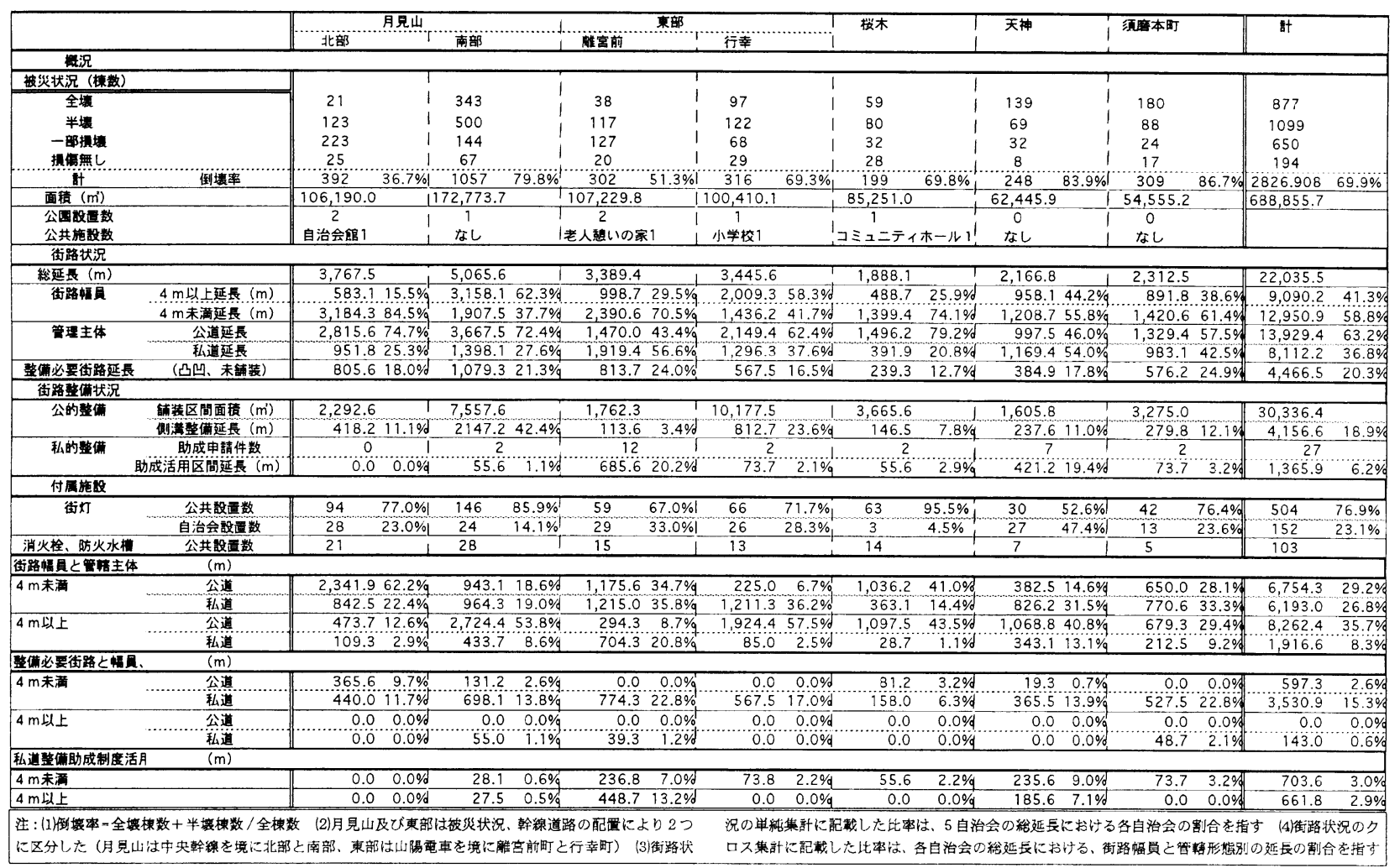

されている。(2)月見山南部で区画整理実施区域を除いた区域（1) を除く区域）は，準幹線道路である月見山線に近い西部を中心に， 殁ど幅員 $4 \mathrm{~m}$ 末満の細街路により構成されている。(3)月見山北部 および東部の区域では, 旧西国街道が, 月見山線, 離宮道の準幹 線道路を東西に連結し, その内部を細街路が網羅している。特に 中央幹線以北の区域 (月見山北部, 離宮前町) では, 網の目状の 幅員 $4 \mathrm{~m}$ 末満の細街路で, 区画が不整形に形成されている。月見 山北部および離宮前町では, $4 \mathrm{~m}$ 未満の細街路が平均して 77.9 \%である。(4)離宮道以西は, 離宮道之国道 2 号線, 千森線の幹線 道路および準幹線道路を, 幅員 $4 \mathrm{~m}$ 以上の細街路（旧西国街道な ど）が東西と南北に連結している。各地区の $4 \mathrm{~m}$ 未満の細街路の 比率は, 桜木が $74.1 \%$ 之高く, 自治会範囲区域に旧西国街道が 通る天神，本町がそれぞれ $55.8 \% ， 61.4 \%$ ある。

\section{(2) 管理主体}

幹線道路を除く, 事例地の地区内街路の総延長に対する公道の 割合は $64.9 \%$, 公道のうち $4 \mathrm{~m}$ 末満は $45.0 \%$ で, 街路総延長の $35.7 \%$ 占める。戦後のミ二開発により土地が細分化され, 公道 と公道を連結するように幅員 $4 \mathrm{~m}$ 末満の私道が張り巡らされた。 各自治会毎の私道の比率は, 離宮前と天神が約 $55 \%$, 行幸と本 町が約 40\%, 月見山が約 25\%, 桜木が約 20\%と格差が見られる。 事例地で, 現時点で震災後に私道を公道化した筒所はない。

\section{(3) 震災後の街路の整備状況}

震災後の行政による公道の舗装や側溝整備は, 1995 年の災害 查定を基に, 復旧整備が行われた。事例地での舗装面積は 30,33 $6.4 \mathrm{~m}^{2}$, 側溝整備延長は $4,155.6 \mathrm{~m}$ である。私道整備は民間の整備 が基本であるが, 神戸市の助成制度があり（表一 2 ), 特に震災 後は神戸市と阪神・淡路大震災復興基金による期限付きの助成制 度が設けられた。事例地では計 27 筒所が後者の制度の適用を申 請し, 整備が行われている。自治会および町毎の比較では離宮前 と天神が多く, 既述の私道分布と合致する。幅員別では, $4 \mathrm{~m}$ 末 満が 17 筒所となっている。一方, 凹凸や未舗装の街路は街路総 延長の $20.2 \%$ にのぼり, 私道で幅員 $4 \mathrm{~m}$ 未満の街路は $15.3 \%$ で,
助成制度活用の延辰の約 2.5 倍が残されている。

\section{(4) 施設配置と震災後の整備状況}

[ゴミ収集施設] 生ゴミステーションは，約 $20 〜 40$ 户単位で 設置されており, 收集車の進入可能な範囲で細街路にも配置され ている。荒ゴミステーションは幅員 $4 \mathrm{~m}$ 以上の街路に配置されて いるが，これは車両進入条件や収集作業上の制約による。

[掲示板］掲示板の設置に対しては神戸市の各区で制定された 助成制度がある。事例地では震災によって多くの掲示板が損壊し たが, 震災後助成制度を活用して設置したところはない。聞き取 り調查では, 手続きが煩雑で, 自治会も費用負担が必要で, 自治 会役員が手作りで補充したところが多い。実際には掲示板のない 箅所にも多く掲示物が張られている。

[街灯] 神戸市が管理する街灯は, 設置基準に基づき公道を中 心に設置されている。自治会による街灯の設置, 維持管理では神 戸市の助成制度がある。また震災により補修，更新が必要な街灯 については，阪神・淡路大震災復興基金による助成制度があり， 各自治会で制度を活用して補修，更新を行っている。自治会によ る街灯設置数の比率は神戸市の設置数の $23.1 \%$ である。

自治会によって設置，管理されている街灯のうち，設置総数の 73.5\%は私道で幅員が $4 \mathrm{~m}$ 末満の細街路にあるが, $13.3 \%$ は公道 で幅員 $4 \mathrm{~m}$ 末満の細街路にも設置されている。また自治会毎に,

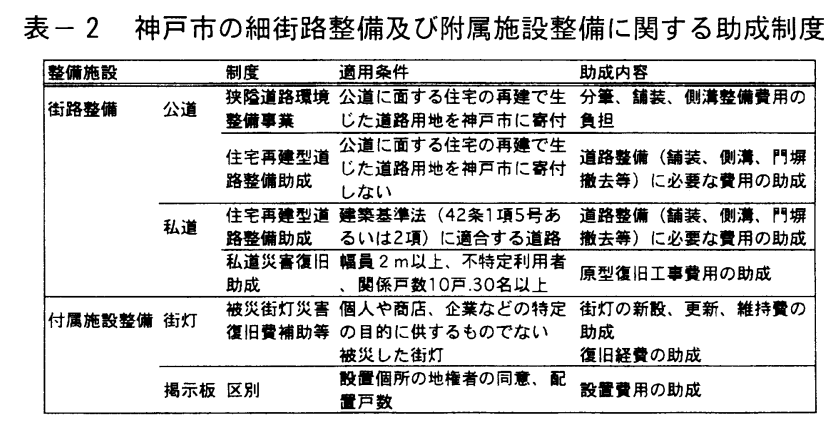


各区域内の公道, 私道の分布状況は異なるため, 自治会の街灯設 置数にも格差が見られる。天神では自治会が設置する街灯の比率 が $47.4 \%$ と行政の管理数に匹敵する。

[消火施設］消火栓, 防火水槽, 消火用ボックスは公道, 公園, 小学校に設置され，マンションや商店等で私設消火栓や送水管を 整備するところがある。自治会毎に見ると，天神と本町の設置数 が少ない。特に本町は, 細街路が密集する区域にはマンションの 敷地内の送水管が 1 ヶ所設置されているのみである。

(5) 小括

事例地の街路空間を空間形態之管理主体から 4 分類し，その特 質について, 分布状況, 管理方法, 整備状況の観点から述べる。 (1)公道で幅員 $4 \mathrm{~m}$ 以上の街路は，事例地の街路総延長の $35 \%$ を 占め，区画整理実施区域に集中し，月見山南部之東部行幸町の一 部にあたる。管理主体が行政で，附属施設も配置基準に則って整 備されている。震災後の行政による復旧整備は殆ど終了している。 (2)公道で幅員 $4 \mathrm{~m}$ 末満の街路は事例地の街路総延長の $29 \%$ を占 め, 月見山北部, 桜木, 離宮前に多い。管理主体が行政であるこ とから, 基本的には行政が附属施設を整備するが, 街灯の施設配 置状況では，自治会か設置した街灯総数の $13 \%$ が，この街路に 配置されている。空間形態により整備の必要性が生じ，住民が補 完的に管理を行っているといえる。震災後の道路本体の復旧はほ ぼ終了しているが，整備を必要とする箇所が離宮前町や月見山の 北部に多い。月見山北部は震災による被害が比較的小さいため, セットバックによる街路空間の整備の機会は少なかったといえる。 (3)私道で幅員が $4 \mathrm{~m}$ 以上の街路は, 街路総延長に占める割合が 8 \%と少ない。管理は, 街路整備は個人や街区単位で行うが, 附属 施設の設置, 管理は自治会が行っている。震災後の街路整備はほ ほ終了している。

(4)私道で幅員が $4 \mathrm{~m}$ 未満の街路は, 東部, 天神, 本町に多い。街 路総延長に占める割合が $26 \%$, 通り抜けのあのあ多いことか ら, 形態的には公道と一体となって, 事例地の街路網を形成して いる。管理は, 街路整備は個人や街区単位で行うが, 附属施設の 設置, 管理は自治会が行っている。街路整備が滞っており, 安全 性に問題がある。附属施設の整備も消火栓, 防火水槽の配置は基 本的になされていない箇所が多い。街路空間の抱える課題が集中 しているといえる。

\section{5. 震災前後の住民による街路空間の管理実態}

事例地の自治会組織による, 震災前〜震災時〜復興期にわたる オープンスペースの管理について表ー3にまとめた。以下に各自 治会毎に(a)地区内の主要な公共施設（以下公共施設）の配置及び 活動の経緯と震災時の街路空間管理の対応, (b)震災前後の街路空 間の共通点，(c)震災前後の街路空間管理の変化について見ていく。 記述内容は街路管理が中心であるが，本研究の目的の 1 つである, コミュニティによるオープンスペース管理を明らかにするため, (d)復興期における公園, 更地の管理等 ${ }^{11)}$ についてむ言及する。

(1) 月見山連合自治会

(a)月見山は 1993 年頃から福祉やまちづくり活動を中心に展開し てきた。公共施設としては自治会館と公園があり, 震災時には物 資配給や情報提供のための地域拠点として運営された。自治会と しては瓦碟置き場を幹線沿いや公園に指定している。また有志に よる夜回りが行われた。

(b)街路空間の管理としては, 震災前より街路空間の維持管理とし て, ゴミ処理の当番制やクリーン作戦を展開し, 公道の街路整備 や施設整備に関しても住民の要望に対応していた。防火対策では, 各町毎に消火器を設置したり，消火訓練を行っていた。

(c)復興期は, 防災対策として, 震災時に既存の防火水槽が使用不 能であったことから, 耐振性の防火水槽の設置を行政に要望し,
地区内の公園に設置され，震災を教訓とした整備が実現した。 住宅再建と細街路拡幅の観点から，自治会としてセットバック の必要性について広報している。特に被害の大きく, 基盤整備が 不充分な地区は，街路と共に民有地を流れる側溝の整備の必要性 から，1998 年より神戸市やコンサルタントなどの専門家の協力 を得て, 街区単位のまちづくりについての勉強会を開催している。 また天井川右岸線に隣接する天井川公園の全面改修に際しては, 行政と連携し住民参加による計画づくりを行っている。

\section{（2）東部自治会}

(a)東部は 1994 年に区画整理事業構想が持ち上がった際に組織改 革が行われ，福祉やまちづくり活動等を展開してきた。公共施設 としては小学校, 公園, 市立老人款いの家がある。震災時には小 学校はもとより, 後者の施設についても自治会が行政と交渉し, それぞれ地域拠点，避難所として運営した。自治会としては瓦磻 処理の優先順位，処理方法について業者に指定したり，有志が始 めた夜回りを引き継いでいる。

(b)街路空間の管理では, 震災前からゴミ処理やクリーン作戦等の 維持管理が見られている。

(c)復興期は, 公道の整備必要個所の調査・要請, 私道の整備助成 制度の広報, 住宅再建時の側溝整備の地権者への要請などの対応 をしている。街灯の必要個所を役員が調查し, 私道を中心に設置 した。夜回りは地域に盗難事件が頻発することなどから, 現在も 週 1 回程度で夜間パトロールとして継続している。

また街路の拡幅については, 震災前は細街路の密集する区域の 一部が私道と接する市有地となり, 復興期に復興計画の街路事業 の換地として宅地化されるにあたり, 付近住民が拡幅の要請を行っ ている。この区域は震災前火事があり，拡幅の要請には自治会の 協力を得て 2300 人の署名により拡幅が実現している。

(d)震災によって阪神高速道路が通行不可となり, 市内中心部と郊 外を結ぶ幹線が交通容量を超え，近隣商店街や離宮前町内の通過 車両が増加したため，住民へのアンケート調査を行った上で自治 会と商店街が警察と協議し, 1995 年 12 月より交通規制を実施し た。その結果行幸町や離宮前町の他の街路の通過車両が増加した ため，その対応策を検討するため，地区内交通量について事後調 査を実施するなどの対応をとった。

\section{(3) 桜木町自治会}

(a)桜木には公共施設として市民公園があるが震災時に利用される ことはなく，町内の宗教施設が避難所となった。瓦砂撤去の優先 順位や方法について解体業者に指定すると共に避難所で集会を開 き，瓦磷処理方法を住民に周知した。夜回りは自治会役員を中心 として有志が行った。

(b)街路空間の管理では震災前からゴミ処理等の維持管理がある。 (c)復興期は, 維持管理を継続すると共に, 街路や付属施設の整備 で，公道整備の優先順位や整備方法の指定，私道の整備助成制度 の情報提供を行った。防災対策としては消火栓の位置を確認し住 民に広報している。

また 10 回に及ぶ住民集会を開催し，1996 年には住民によるま ちづくりの素案を作成している。この内容には，セットバックに よる町内の街路網整備や車両進入対策などが盛り込まれている。 （4）天神町 $3 \cdot 4 \cdot 5$ 丁目自治会 (a)天神には公共施設がなく, 震災時には暫定的に自治会を結成し て, 神戸市と交渉の上, 市有の空地を地域拠点として活用した。 瓦碟が幹線道路にある荒ゴミステーションの容量を越えたため, 住民有志が住民へのマナー向上の呼びかけや処理を行った。更地 に避難していた住民を中心に自主的な夜回りを行った。 (b)街路空間の管理では, 震災前からゴミ処理の当番制があった。 また自治会が設置した街灯の維持管理を行っている。 (c)震災後, 1996 年に自治会が再編され，活動を本格化させた。 
住民のオリエンデーリングやアンケート， ヒアリングを行い, 公道および付属施設の 整備必要個所について調査・整備要請した。 私道整備については助成制度の情報提供を 行った。防災対策としては防火施設の位置 確認を行った。

\section{（5）須磨本町自治会}

(a)本町にも公共施設はなく, 震災時に地域 に残った住民は僅かで, 物資や情報の提供 はなかった。震災時には夜回りが有志によ り行われた。地域に帰る住民が増えるに伴っ て瓦磂の量む増加するため, 有志が行政と 協議し幹線道路沿いを瓦啋置き場に順次指 定した。住民間の情報共有や空間管理の方 針の決定は, 地域拠点が確保できない状況 で，個人のガレージで集会を開いたり，夜 回りの作業を通じて行われた。

(b)街路空間の管理では, 震災前にはゴミ処 理や街路整備に関する活動はなかったが， 震災後に自治会を再編し, 自治会活動の方 針を決定するにあたって住民のアンケート 調查を実施している。街路空間の維持管理 としてクリーン活動を開始している。街路 や付属施設の整備については, 公道では整 備を要請し, 私道整備では助成制度の情報 提供を行った。防火施設の位置確認と広報 も行っている。

\section{(6) 小括}

事例地の各自治会の街路空間管理の共通 点と相違点より，コミュニティと街路空間 の相互関係とその変化について，以下のこ とが明らかとなる。

(1)街路空間を巡る課題としては, ゴミ処 理, クリーン活動, 街路整備, 附属施設整 備などがあった。月見山, 東部では震災前

\begin{tabular}{|c|c|c|c|c|c|c|c|}
\hline 期要 & & 年 & 月見山 & 東部 & 挼木 & 天神 & 須磨本町 \\
\hline \multirow[t]{3}{*}{ 人口 $(*)$} & \multirow[t]{3}{*}{ (人) } & 1990 & 6659 & 3203 & 1013 & 1090 & 1090 \\
\hline & & 1995 & 4763 & 2344 & 733 & 529 & 514 \\
\hline & & 1998 & 5297 & 2586 & 925 & 748 & 802 \\
\hline \multirow[t]{3}{*}{ 世带数 (*) ( } & \multirow[t]{3}{*}{ （世帯） } & 1990 & 2534 & 1264 & 380 & 379 & 434 \\
\hline & & 1995 & 1802 & 934 & 281 & 189 & 215 \\
\hline & & 1998 & 2434 & 1195 & 383 & 350 & 336 \\
\hline \multicolumn{2}{|l|}{ 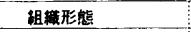 } & & 役貝会、部会 & 役員会、部会 & 役貝会、委員会 & 役員会 & 役員会 \\
\hline \multicolumn{2}{|l|}{ 役員数 } & 1998 & 69 人 & 38人 & 24 人 & 23 人 & 14人 \\
\hline \multirow{2}{*}{\multicolumn{2}{|c|}{ 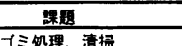 }} & 時期 & & 各目治会の対応 & & & \\
\hline & & 踚災前 & 当番制/クリーン佸動 & 号当番制/クリーン话動 & 罗当番制 & T当番制 & 1な \\
\hline \multirow{2}{*}{\multicolumn{2}{|c|}{ 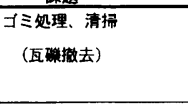 }} & 票災時 & 街路を瓦磷貫き埸に & 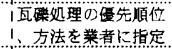 & 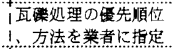 & 住民が对ランティア & 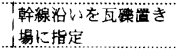 \\
\hline & & 復興期 & 農炎前と同U & 辰多前と同し & 当番制 & 当番制 & 当番制/クリーン活 \\
\hline \multicolumn{2}{|l|}{ 夜回り } & 罢苝時 & $\begin{array}{l}\text { 有志による(自治会 } \\
\text { 役員を中心に) }\end{array}$ & $\begin{array}{l}\text { l有志で委員をつくる } \\
\text { (後に自治会として } \\
\text { 术ランテイア募香) } \\
\end{array}$ & 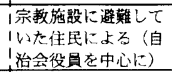 & $\begin{array}{l}\text { 便地に避難していた } \\
\text { |住民など(自治会役 } \\
\text { 員を中心に) }\end{array}$ & $\begin{array}{l}\text { 地域に残っていた住 } \\
\text { | }\end{array}$ \\
\hline \multirow{4}{*}{ 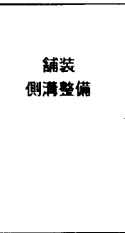 } & \multirow[t]{2}{*}{ 公道 } & 捄悠前 & 要望があれば対地 & $1+52$ & なっ & な2 & Tなし \\
\hline & & 復舆期 & \begin{tabular}{|l} 
整满简所、スケジュ \\
一ルを住民提示
\end{tabular} & $\begin{array}{l}\text { 整備の必要简所を調 } \\
\text { 焦、要諳 }\end{array}$ & 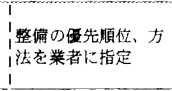 & 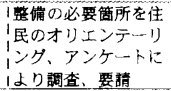 & 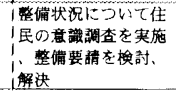 \\
\hline & \multirow[t]{2}{*}{ 私道 } & 置炎前 & なし（個人、街区） & なし（個人.街区） & 秃 (個人，街区) & けし (㑬人.街区) & なし（個人.街区） \\
\hline & & 復舆期 & $\begin{array}{l}\text { 住民へ整偏助成制度 } \\
\text { の情坡提供 }\end{array}$ & 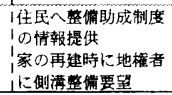 & 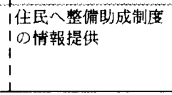 & 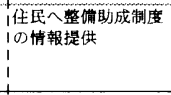 & 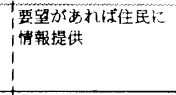 \\
\hline \multirow{3}{*}{ 街奵 } & 公共 & 䆖災前 & 要望があれは対応 & なし (個人) & はなし (個人) & 1自治会役員 & なし（個人） \\
\hline & & 復畟期 & 補格/增設の要㤠 & 補修增没の要望 & 、整修の要望 & “莗修の要望 & 棟到の要望 \\
\hline & 自治会 & 復興期 & 補修/增設 & |補增/増設 & ）補修/堌設 & 溥修/增設 & 速被 \\
\hline \multicolumn{2}{|l|}{ 揭示板 } & & 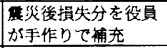 & 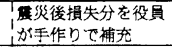 & 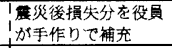 & な2 & 信災後損失分を補充 \\
\hline \multirow{2}{*}{\multicolumn{2}{|c|}{ 消火栓/防火水槽 }} & 双災前 & $\begin{array}{l}\text { 消火訓粯、各町每に } \\
\text { 消火器を設益 }\end{array}$ & 1 な2 & な2 & な2 & な⿰ \\
\hline & & 得舆期 & 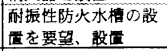 & & 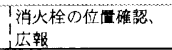 & 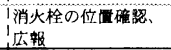 & 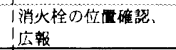 \\
\hline \multicolumn{2}{|l|}{ 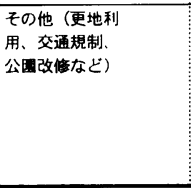 } & 復興期 & 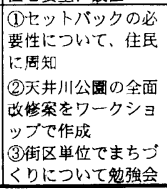 & 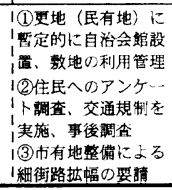 & 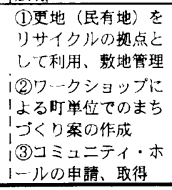 & 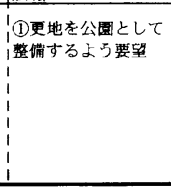 & 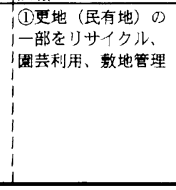 \\
\hline \multicolumn{6}{|c|}{ 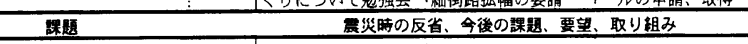 } & & \\
\hline \multicolumn{3}{|l|}{ 維持管理 } & 特になし & 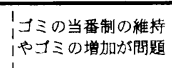 & $\begin{array}{l}\text { 地域外からの荒さミ } \\
\text { 就の対応 }\end{array}$ & $\begin{array}{l}\text { 地域外からの荒コミ } \\
\text { 成対比 }\end{array}$ & $\begin{array}{l}\text { 地域外、マンション } \\
\text { 住民からの荒コミ } \\
\text { 1への奶応 }\end{array}$ \\
\hline \multicolumn{3}{|l|}{ 辣装 } & 特になL & 特になし & 特R+sL & 特RなL & 特に大L \\
\hline \multicolumn{3}{|l|}{ 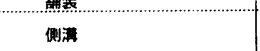 } & $\begin{array}{l}\text { 民有地の側澺整備は } \\
\text { 行政の対応子し }\end{array}$ & $\begin{array}{l}\text { 整備を要諳してもな } \\
\text { かな施がない }\end{array}$ & $\begin{array}{l}\text { 公道の雨水の渄水か } \\
\text { 恶し }\end{array}$ & |特になし & 特になし \\
\hline \multicolumn{3}{|l|}{ 街奵 } & 特になし & 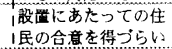 & 特になし & |特になし & $\begin{array}{l}\text { 整備の必要性のある } \\
\text { 簿所がるる }\end{array}$ \\
\hline \multicolumn{3}{|l|}{ セットバック } & $\begin{array}{l}\text { 一体的整偏にあたつ } \\
\text { ての住民の合意形成 }\end{array}$ & 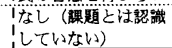 & 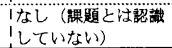 & $\begin{array}{l}\text { 住民の自助努力たけけ } \\
\text { では進まない }\end{array}$ & $\begin{array}{l}\text { 個人の住宅再建には } \\
\text { |口を出せない }\end{array}$ \\
\hline \multicolumn{8}{|c|}{ 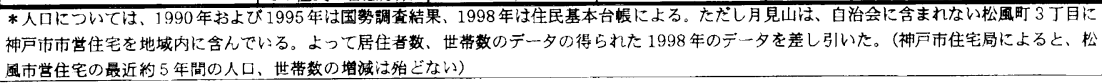 } \\
\hline
\end{tabular}
から活動内容を多様化させ, 街路空間の管理としては, クリーン 活動，防災施設整備などを行っていた。震災時，震災後の対応に おいては, 夜回りや情報共有など, 地域内部において住民有志に より形成された暫定的な組織による対応があり, 他方で瓦砅処理 や街路整備など行政への空間整備要請に携わる既存の組織による 対応があった。これらは必要性に応じた管理であったが, 東部の 夜回りのように, 震災時に発生した管理が, 平常時に移行した段階 で，日常的な防犯活動として位置づけ直されているケースもある。

(2)桜木, 天神, 本町では, 既存の地域住民組織の対応や公共地 域施設むない状況で，住民有志による街路空間の管理が行われた。 天神や本町のように, 既存の自治会が震災時の空間管理において 機能しなかった地区では，震災が自治会形成を促したといえる。 こうした空間管理のプロセスは, 街路舗装や街灯整備などの復旧 が終了した後も, ゴミ処理や清掃といった震災後の自治会の空間 管理の内容の変化をもたらしている。

(3)各自治会の対応によって, 瓦砂処理や夜回りなど, 震災によっ て生じた街路空間の課題の一部は解消した。街路整備や街灯につ いても一定の成果は得られているといえる。しかし, 民有地の側 溝整備という管理主体に関わる課題や，マンション住民の增加に 伴うゴミ収集といった, 震災後の土地利用と幅員が狭险な細街路 に関する課題が提起されている。

(4)各自治会では, 復旧に留まらない街路空間への働きかけを試 みており, 交通規制, 街区単位や町単位の計画案策定の取り組み,

街路以外の空間では更地利用, 公園改修などがみられる。

\section{6. 考察 一街路空間に見るオープンスペース管理の諸相 一}

本節では, まず既述の分析結果より，事例地の街路空間の課題 について空間的形態と空間管理制度の関係性より整理し, 街路空 間の管理プロセスに見られる管理主体の関係とコミュニティの役 割について明らかにする。その上で，今後の事例地の街路空間管 理の方向性について考察を進める。

\section{(1) 空間的課題の構造}

事例地は細街路が公道私道の区別なく, 広く分布し地域の街路 網を形成していた。細街路については, 歩行の危険性やゴミ処理 といった日常的な課題を抱え, 特に幅員 $4 \mathrm{~m}$ 末満の細街路では 車両が進入できず，施設も整っていない箇所が多い等の防災上の 課題を抱えていた。事例地では, 震災によって顕在化した狭隘な 幅員, 街路及び付属施設の整備等街路空間に関する空間形態と施 設配置の課題は，震災後に改善されたとは言えない状況だった。

以上の街路空間の形態的な課題は, 街路空間の管理制度と密接 に関係していた。公道の管理は，行政独自の調查や住民からの整 備要請に基づき整備がなされ(1)，住民と行政の間の相補的な関係 を示していた。一方公的整備の行われない私道の細街路では, 街 路や付属施設の整備が滞り, 街路空間の抱える課題が集中してい た。住宅再建の際のセットバックも, 個人の自助努力の限界が住 民から指摘されている。 
細街路の整備に関する神戸市の施策としては, 公的整備がなさ れない私道に対する助成制度や住宅再建型の道路整備事業が打ち 出されている。しかし細街路整備の諸事業の進渉状況を見ると, 事例地では私道整備助成の活用は見られたが, 他の事業に関して は現時点では活用されておらず12)，実際の空間整備事業の運用は 個人, 街区, 自治会に委稀られている。

\section{(2) 街路空間管理におけるコミュニティの役割}

事例地の街路空間整備におけるコミュニティの対応は, 被災状 況や公道, 私道の空間的配置, 地域住民組織の活動の経緯によっ て多様であった。公道では行政への整備の要望, 私道では情報提 供や整備要請があり，一定の成果が見られた。街路空間の管理に おいては，地域住民組織は行政による制度的な管理と個人による 私的な管理を媒介する領域に携わっているといえる。

事例地では震災時に街路空間の管理において既存の地域住民組 織が機能しなかった地域で, 震災を継起にコミュニティが再編さ れる事例も見られた。また交通規制や街区単位でのまちづくりの 勉強会, セットバックを含むまちづくり案の作成等, 復旧に留ま らない街路空間への㗢き掛けが見られる。これらの組織改革や空 間整備の情報や知識の共有化，空間管理の試みは，住民が新たな 街路空間を創造する必要性を認識し,コミュニティとして積極的 に取り組んでいると理解されよう。

(3) 街路空間整備の方向性

今後, 事例地の街路空間の整備を進めていくためには，住民が
より積極的に街路空間整備を検討するよう促す事業メニューを検 討していく必要がある。例えば, 地区計画やまちづくり協定と街 並環境整備事業の併用を想定した, 街路空間の整備や助成内容の 多様化や, 整備メニューを積極的に提示することが挙げられる。 一方で, 街路空間整備を実践していくにあたっては, 住民と行政 が双方から働き掛け, 事業メニューを検討し, 選択していくプロ セスを含めた, 協働の管理システム構築の必要性む導き出される。 その見地から，本稿で示したような地域住民組織一自治会一 は，自主的な空間管理を実践し，住民個人と行政とを中間的に媒 介することから, 住民と行政間の情報や知識の共有化, 合意形成 プロセスにおける重要な位置を占めるであろう。

\section{7. おわりに}

本稿で示した事例地の街路空間の整備におけるコミュニティと 行政の関係性は, 街路空間に留まらず，オープンスペース整備一 般にあてはまる。コミュニティによるオープンスペース整備の実 績が, 非常時における物的被害の軽減, コミュニティによる救援 活動に寄与したという評価の可能性を有している ${ }^{13)}$ 。今後, オー プンスペース整備の推進のためには，コミュニティと行政の新た な空間管理システムの模索が必要とされるであろう。

本研究の調查に当たり, 神戸市の関係部局, 西須磨 5 自治会の 方々には多大なご協力をいただいた。ここに感謝を記す。
補注および引用・参考文献

1) 日本造園学会阪神大震災調査特別委員会 (1995)：阪神大震災緊急調査報告書, 若生 謙二他（1998）：阪神・淡路大震災後の公園 の避難地利用について：ランドスケープ研 究 61(5), 773〜 777, 寺川政司 (1996)：阪 神・淡路大震災におけるテント村の居住環 境 : 都市問題, 55 71

2) 街路空間の認知や利用を取り上げた研究は 多い。野嶋政和他（1997）：阪神淡路大震 災以後の復興まちづくり活動におりる街路 空間の利用・認知亡街路事業の影響に関す る研究 : 都市計画論文集 32, 739 745, 全 現美（1995）: 住民意識からみた団地屋外空 間整備のあり方に関する研究 : 都市計画論 文集 $30,193 \sim 199$ 等。空間認知については, 加藤仁美 (1996)：『空間意識网』による住 民の共通な環境イメージ：日本建築学会計 画計論文集 479 号, $159 \sim 168$

3) 轟慎一他 (1993)：低層集合住宅団地におけ る管理形態からみた共用空間の問題対応に 関する研究 : 造園雑誌 56（5），301～306, 本光章一他 (1991)：修復型まちづくりにお ける公的空間拡大過程に関する研究：都市 計画論文集 $26,625 \sim 631$ ，木下勇（1997）： 太子堂地区を事例之する参加型地区計画に 掞けるオープンスペース創出過程に関する 研究：ランドスケープ研究 60 (5)，691〜69 4, 藍澤宏他（1998）：近隣住民による屋外 共用空間の保全, 再整備に関する研究：日 本建築学会計画系論文集 508 号, 51 58 等

4 ) 本稿の事例地の一部を対象とした, 安藤元 夫他（1997）：木造密集市街地の細街路，狭 小宅地における住宅再建の困難性に関する 研究 : 都市計画論文集 $32,751 \sim 756$ では,
住宅再建の観点から西須磨地区における細 街路の抱える課題について論じている。震 災後のセットバックの現状については，小 浦久子他（1998）: 被災地の住宅の個別再建 による街区内細街路の変化に関する研究 都市計画論文集 $33,847 \sim 853$ が考察してい る。

5 ）予備調査として，都市問題研究所（1980） 地域住民組織の実態分析：勁草書房，蓮見 他 (1990): 都市政策之地域形成：東京大学 出版会等の文献調査, 行政, 住民へのヒア リングを行った。その結果, 街路空間の管 理主体として目治会, 婦人会が挙げられた が, 後者は震災後暫く活動を休止するケー スがあったことや，震災後の地区内街路空 間の管理については自治会の管理の範囲と 内容が最も多様であったため，本研究の調 查対象とした。また本稿では詳細な聞き取 りが可能な 5 自治会を選定し, 調查対象之 した。

6 ）神戸书西部事務所：平成 9 年舗装補修台帳, 私道災害復旧工事助成受け付け台帳, 平成 9 年側溝整備現況調查台帳

7 ）道路法で認定されない里道は，行政が管理 責任を負うことから公道とした。寶金敏明 (1995)：改訂里道・水路・海浜—法定外 公共用物の所有之管理：ぎょうせい

8 ) 震災時を地震加ら事例地の瓦礫撤去加終わっ た 1995 年 6 月頃まで, 復興期をそれ以降の 地区内街路空間の復旧, 整備が本格化した 時期とする

9 ）自治会報の他，桜木町自治会（1996）：市長 への手紙や, 西須磨まちづくり想談会 (1997)： 住民主体への挑戦 : エピックがある。

10）神戸市の「西須磨地区整備計画調査報告書
（1994 年）では，西須磨地区として本稿の事 例地の他，隣接する 2 町が含まれる。一方 参照文献に挙げた，住民有志発行の「住民 主体への挑戦」では，行政よりもさらに広 い地域を指す。筆者は，震災で大きな被害 を被り，既成市街地としての課題を住民が 共有する地区として, 後者の範井を西須磨 地区とみなした。本稿で扱う5 自治会の範 囲は，筆者が定義する「西須磨地区」では $1 / 2$ 以上の面積に相当し，行政の定義する 「西須磨地区」では約 $3 / 4$ の面積に達して いるため, 本稿の事例地を「西須磨地区」 と記述することにした。

11）駐車場等の震災前から用途が明確な空地に 関しては，事例地では震災直後に住民の一。 時的な集合や自治会の集会への利用等を把 握した。復興期では，住民の個別交涉で資 材搬入時の利用等も見られた。しかしこう した空地の管理へ自治会が関与したケース は見られなかった。

12）震災後 3 年間に，当地域を管轄する神戸市 建設局西部事務所には，每年 $2 \sim 3$ 千件の 整備要請があり, 公的整備が実現している。

13）震災前よりあった私道整備事業は，震災後 災害復旧事業の狭隘細街路整備として単独 の事業メニューが新たに策定された。神戸 市全体で 1996 98 年度で狭盒道路環境整備 事業が 8 件, 1997 98 年 9 月時点で公道に 面する住宅再建型道路整備助成が 6 件, 同 年度で私道に面する住宅再建型道路整備事 業が 2 件である。

14）鈴木克彦（1998）：震災時における建築協定 の役割に対する住民評価について-阪神・淡 路大震災による被災地区を中心として－：日 本建築学会計画系論文集, 165-172

Summary: The purpose of this study is to research partnership between local government and neighborhood residents on the maintenance system of neighborhoods streets. We analyze street and artery form, the maintenance of open space, especially street, and its actual situation, on Nishisuma District, Suma Ward, Kobe City, after the Great HanshinAwaji Earthquake. The results are follows; 1) In the case of Nishisuma, government and neighborhoods residents recognize the problems of street, width and situation of attachment structure. 2) In the process of open space management, the partnership of government and neighborhoods residents is indispensable. 